\title{
Nuclear proteins: finding and binding target sites in chromatin
}

\author{
Martin E. van Royen • Angelika Zotter • \\ Shehu M. Ibrahim • Bart Geverts • \\ Adriaan B. Houtsmuller
}

Published online: 22 December 2010

(C) Springer Science+Business Media B.V. 2010

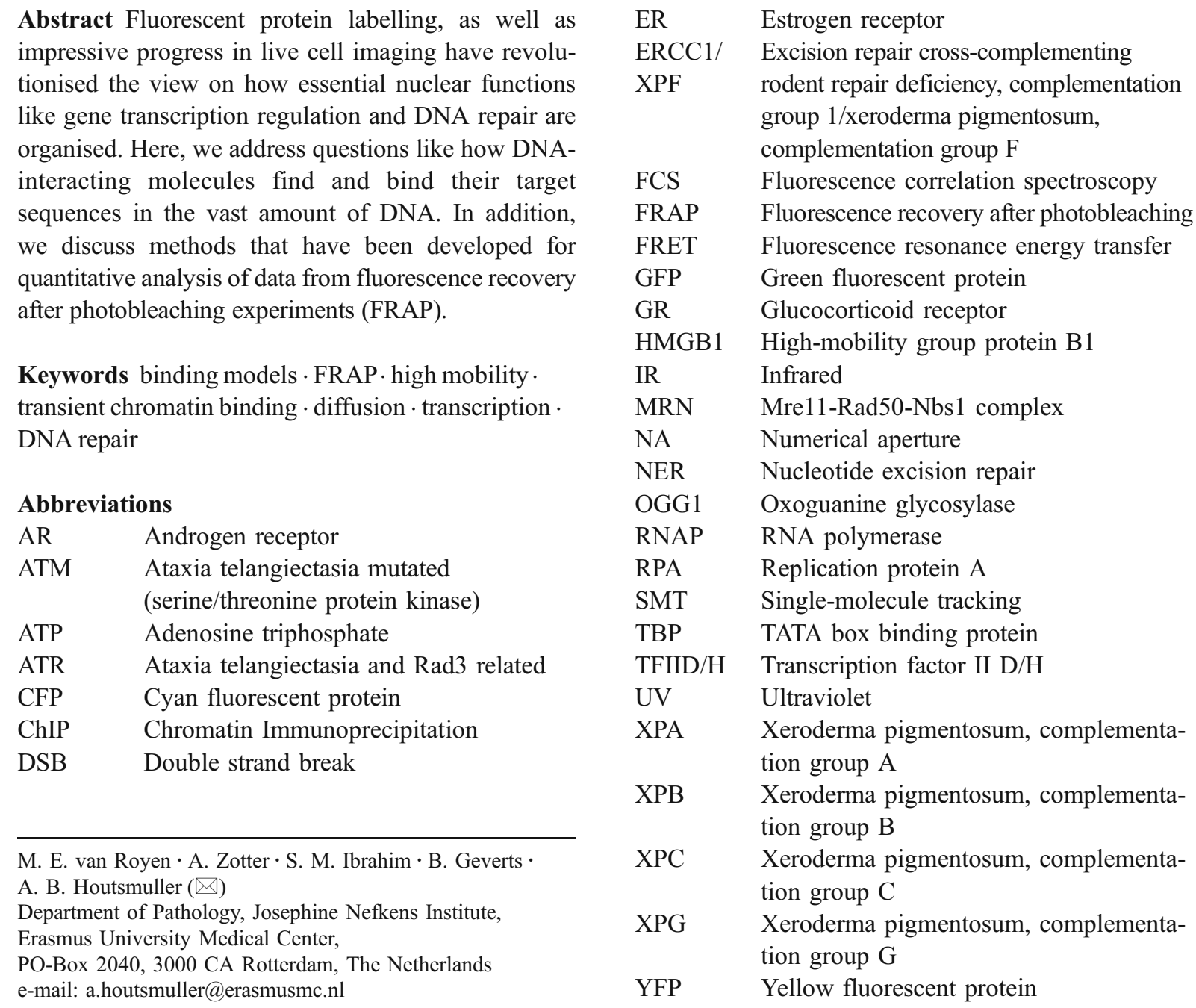




\section{How do nuclear proteins find their targets?}

To exert its function, a nuclear factor involved in, e.g. DNA repair, gene transcription or replication, has to find its target in the enormous amount of DNA and subsequently bind to it, either to DNA directly or to a protein-DNA-complex. The simplest model to account for this, obviously, is one where molecules move by free diffusion and find their targets by random collisions. More sophisticated models include sliding along the DNA strand (one-dimensional (1D) diffusion), along the chromatin surface (2D diffusion), as well as hopping and jumping over the DNA after initial non-specific binding. Below, we discuss these models in detail.

Diffusion and random collision

Before the advent of GFP-tagging and quantitative microscopy assays like fluorescence recovery after photobleaching (FRAP) it was generally assumed that the vast majority of nuclear proteins was assembled in stable functional structures. Only a small portion of the proteins was considered to be engaged in transport towards their target sites, which was thought to be facilitated by sliding along DNA strands (Fig. 1a, b). Once assembled in DNA-protein complexes, proteins were generally assumed to be stably associated until degraded. It was therefore a great surprise to the research community that the first experiments exploring FRAP on GFP-tagged nuclear proteins revealed that several nuclear proteins with various functions, including DNA repair, transcription and splicing factors, are highly mobile, most likely more or less freely diffusing through the nucleus (Fig. 1c; Houtsmuller et al. 1999; Phair and Misteli 2000). A multitude of following studies confirmed the novel view on nuclear organisation in which high mobility is a common feature of most, if not all DNA-metabolising processes in the cell nucleus. The possibility to freely move through the nucleus, in spite of its crowded nature, was further corroborated by the observation that the mobility of fluorescently tagged inert proteins of increasing size depends on their molecular size (Fig. 2a; Bancaud et al. 2009). In addition, proteins involved in DNA repair of single-strand lesions by nucleotide excision repair also diffuse at rates expected for their molecular size (Fig. 2b and c). The only exception is the damage sensor xeroderma pigmentosum, complementation group C (XPC), which likely shows decreased mobility due to frequent transient binding events to undamaged DNA, probing in this way the DNA for potential damage (Fig. 2b). It should be noted, however, that due to molecular crowding, which obviously puts constraints on the mobility of unbound factors, diffusion is probably not completely free, but anomalous (Wachsmuth et al. 2000), and the degree of anomality depends on local circumstances within the nucleus, where in a more crowded region mobility undergoes more constraints than in a less crowded region (Bancaud et al. 2009). In the latter paper, Ellenberg and coworkers conclude from local FRAP and FCS measurements, showing mobility dependency on local chromatin density, that chromatin adopts a fractal structure where the local fractal dimension has a regulatory role in exposing binding sites in the DNA to diffusive proteins. This fractal structure was also concluded from 4C experiments (Lieberman-Aiden et al. 2009). However, at present, it is not clear whether a fractal model is the only model fitting to these data (McNally and Mazza 2010). Moreover, it is also possible that both fractal chromatin arrangement and anomalous diffusion are results of DNA-packing in a crowded environment, rather than prerequisites for proper function. Therefore, further in-depth research will be required to verify whether these phenomena provide mechanisms contributing to the efficiency by which proteins find their targets.

Another common idea that was challenged by live cell studies using fluorescently tagged probes is that genes may be silenced by densely packing them into heterochromatin limiting access of factors required to initiate gene transcription, as it was shown that large protein complexes $(>500 \mathrm{kD})$ and dextrans with similar molecular size have free access even to the most dense chromatin domains (Verschure et al. 2003; Gorisch et al. 2003, 2005).

DNA sliding (1D diffusion)

In spite of the findings above, it is frequently argued that protein movement by merely random diffusion, whether anomalous or not, is not sufficient for finding specific target sequences in the vast amount of DNA at the required efficiency. In this line of reasoning, facilitated transport mechanisms should exist that guide a nuclear factor to its specific binding site, or at least, that enhance the chance for the freely mobile factor to find its target. The efficiency of finding 
Fig. 1 Modes of nuclear protein translocation. a One-dimensional diffusion along the DNA helix. Non-specific contacts of proteins with DNA through electrostatic interactions lead to rotation-coupled 'sliding' along the DNA helix but may be limited to short ranges by obstacles like other sliding factors or DNA-bound complexes. b Obstacles can be bypassed by 2-dimensional diffusion in which a protein diffuses freely on the cylindrical surface of the DNA between sites that are not adjacent in the primary DNA sequence. c Free $3 \mathrm{D}$ diffusion with random collisions resulting in binding to specific and non-specific binding sites. Rapid rebinding to a site close to the initial site or rebinding relatively far from the initial site is also referred to as 'hopping' and 'jumping', respectively. Although 'hopping' and 'jumping' are described as separate models, molecules behave similarly in a model of 3D diffusion with random collision.

d Obstacles can be bypassed by intersegmental transfer where proteins move from one site to another, distant site ( $\sim 400$ bp) by transient binding to both sites and subsequent dissociation from the initial site
A

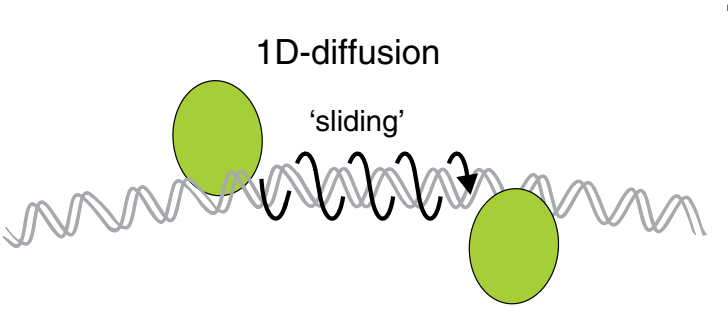

B

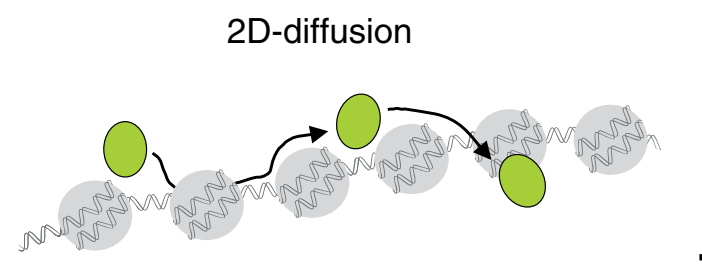

C

3D-diffusion

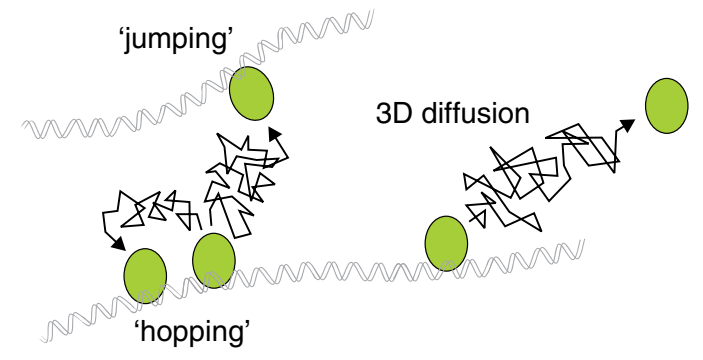

3D diffusion with random collision (Berg 1981; Stanford, 2000; Halford 2004; Gowers, 2005;

Gorski, 2006)

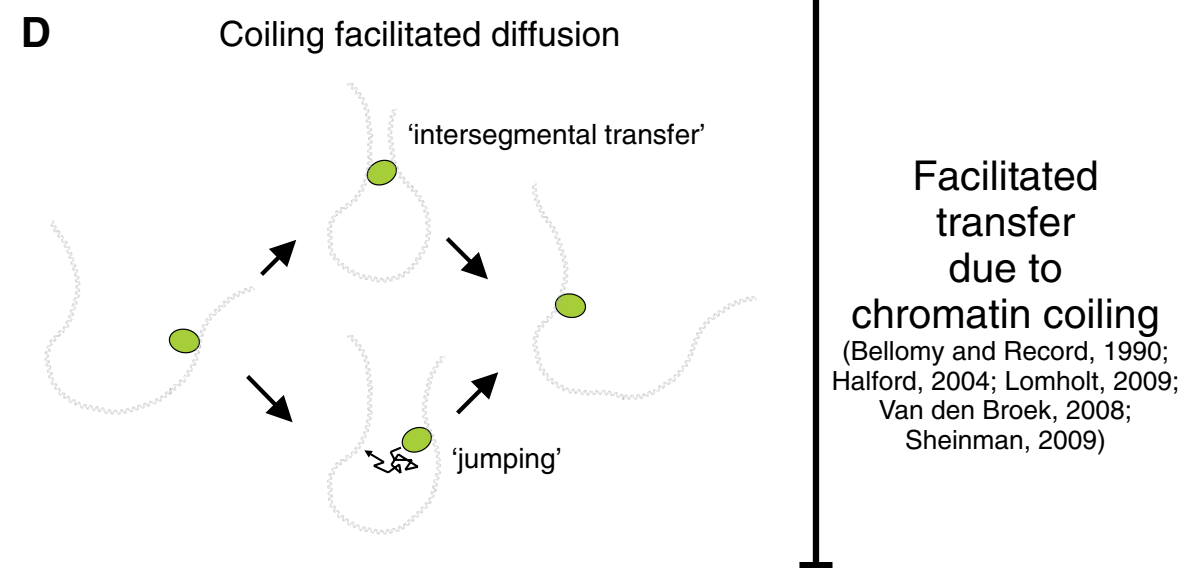

specific binding sites may be increased when diffusion and stochastic binding are accompanied by local scanning mechanisms based on sliding of the protein along the DNA (one-dimensional diffusion; Fig. 1a). In more abstract terms, reducing the dimensionality of diffusion-based reactions in biological systems can greatly increase the efficiency of bimolecular interaction (Adam and Delbruck 1968). Several modes of local 1D scanning mechanisms have been experimentally tested (reviewed in Gorman and Greene 2008). In these models, after aspecific binding to DNA, a protein travels along the DNA while remaining in continuous contact with non-specific binding sites or via a series of negligible dissociation and rebinding events (Fig. 1a) (Berg et al. 1981). Most of the early data supporting such models are based on in vitro 

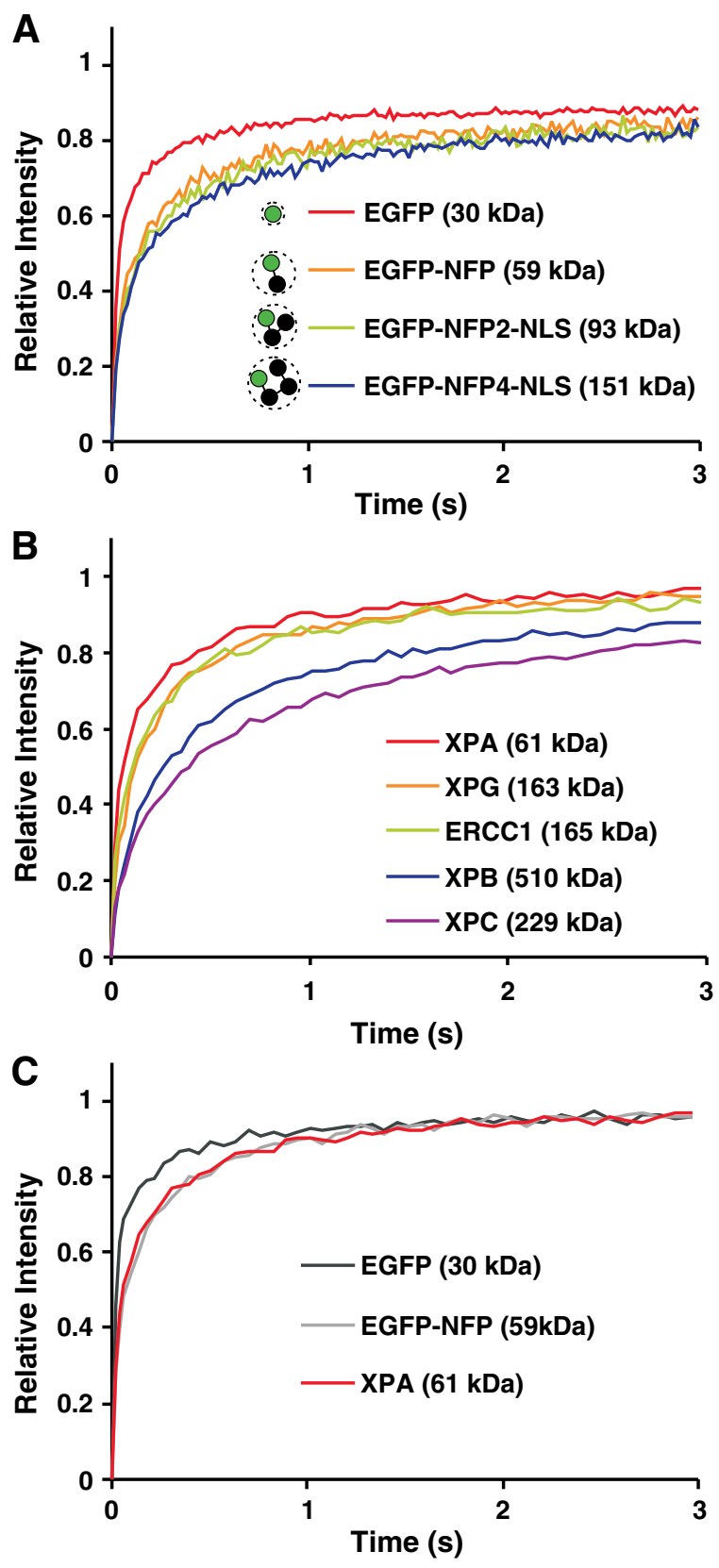

studies of DNA cleavage by endonucleases, where the length of a stretch of double-stranded DNA containing a specific cleavage site determines the rate at which cleavage occurs (Jack et al. 1982; Langowaski et al. 1983; Terry et al. 1987; Jeltsch et al. 1994, 1996; Jeltsch and Pingoud 1998; Wright et al. 1999; Stanford et al. 2000). Alternative experiments using the endonuclease BbvCI which more frequently cleaves nearby nonpalindromic recognition sites when
Fig. 2 FRAP curves of proteins of varying size showing the relationship between diffusion and molecular size. FRAP curves were obtained by briefly photobleaching a narrow strip spanning the nucleus and following the recovery of fluorescence in that strip with short intervals (20 ms (a) or $100 \mathrm{~ms}$ (b and c); described for instance in van Royen et al. 2009). a FRAP curves of protein chains consisting of an increasing number of non-fluorescent GFP-variants and one intact GFP. Schematic drawings indicate that the increase of average radius of gyration (as a measure for molecular size) is largest between GFP and GFP-NFP. b FRAP curves of various DNA repair proteins in the absence of single-strand damage. XPC is the odd-one-out which can be explained by its role in damage detection: its mobility is much lower than expected due to frequent transient binding to (undamaged) chromatin, in this way scanning the DNA for potential damage. c Comparison of FRAP curves of GFP, GFP-NFP and the repair factor XPA in unchallenged cells showing similar mobility of similar-sized XPA and GFP-NFP

they are in the same orientation rather than in inverted orientation indicated that the BbvCI travels from the first to the second site over short distances without dissociation and rebinding (Gowers et al. 2005). In addition to endonucleases, several other DNAbinding proteins have been shown to display 1D diffusion along DNA, using single-molecule detection techniques (Shimamoto 1999; Gorman and Greene 2008). These include DNA repair proteins like Rad51 involved in homologous recombination, oxoguanine glycosylase involved in base-excision repair and postreplicative mismatch repair proteins (Msh2-Msh6), but also transcription factors like RNA polymerase (RNAP), T7 RNAP and the lac repressor (LacI), that show facilitated diffusion along anchored DNA stretches interspersed with three-dimensional translocations (Kabata et al. 1993; Harada et al. 1999; Blainey et al. 2006; Graneli et al. 2006; Wang et al. 2006; Gorman et al. 2007). Assuming that protein sliding is mainly driven by electrostatic interactions with the phosphate backbone, it has been suggested that sliding involves spiralling around the DNA helix (Fig. 1a; Schurr 1975; Gorman and Greene 2008). This was indirectly shown as rotational behaviour of a DNA stretch linked to an asymmetrically labelled bead when dragged over an RNA polymerase-coated coverslip using an optical trap (Sakata-Sogawa and Shimamoto 2004). More recently, statistical analysis of single-molecule diffusion data of eight DNAbinding proteins showed that rotation-coupled sliding along the DNA helix is a general phenomenon in vitro (Blainey et al. 2009). 
However, although it seems clear that many DNAbinding proteins in vitro are able to slide along DNA, studies on living cells to determine to what extent this behaviour contributes to reaction efficiency in vivo are still limited. One interesting study on protein behaviour in living Escherichia coli cells using the lac repressor LacI suggests that one-dimensional diffusion along DNA segments occurs, but in combination with three-dimensional translocation through the cytoplasm (Elf et al. 2007). The most obvious difficulty that may arise in DNA sliding models is the presence of hundreds or thousands of different DNAbinding molecules, each present in tens of thousands of copies, which may considerably hinder each other when moving along the one lane road of DNA. This is a lesser problem in a hypothesised two-dimensional sliding mechanism, where the protein diffuses over the DNA surface, enabling the restriction endonuclease EcoRI to bypass obstacles in vitro (Fig. 1b; Kampmann 2004). In addition, the lack of directionality in onedimensional diffusion may also lower the probability of reaching distant sites, limiting the efficiency of detecting specific binding sites (Gerland et al. 2002).

Hopping, jumping and intersegmental transfer

In addition to these sliding mechanisms, it has also been hypothesised that proteins may bind repeatedly in the same region in an aspecific manner and only freely diffuse shortly through nuclear space before rebinding at another (specific or non-specific) binding site, in this way, enhancing their chances to find their target sites. These short 3-D diffusion events include short intrasegmental hops along the DNA contour, intersegmental jumps between nearby segments and translocations over longer distances in three-dimensional space (Fig. 1c). Because of the larger probability of binding to nearby sites relative to distant sites, in solution the protein will more frequently bind to sites on the same strand of DNA (Halford and Marko 2004). This model is supported by the decreased association time when the DNA conformation is changed from a coiled structure to extended DNA using optical tweezers (van den Broek et al. 2008). It was determined that cDNA coiling leads to a more efficient search rate for specific binding sites (Fig. 1d; Lomholt et al. 2009). Whether this holds true for chromatin binding in the nucleus depends on the relative proximity of functional elements in different stands of DNA in higher order chromatin organisation.
A third alternative is so-called intersegmental transfer (as opposed to intersegmental jumps), which may occur when proteins are capable of binding two sites (Fig. 1d). In this model a protein binds a site distant from its target, and before dissociating binds to another site that is brought into proximity by looping of DNA, thereby generating an intermediate in which the protein is transiently bound to both sites. Because of limited DNA flexibility, intersegmental transfer is restricted to larger steps ( $\approx 400$ bp) (Bellomy and Record 1990).

\section{FRAP analysis}

Before we move on to discussing the way nuclear proteins bind their targets once they found them, we summarise below recent developments in quantitative analysis of fluorescence recovery after photobleaching. FRAP is widely used, not only to determine the mobility of fluorescently tagged proteins, but also the kinetics of interactions with immobile structures. In other words, with FRAP, we can quantitatively assess on- and off-rates from and to DNA or DNA complexes.

FRAP makes use of the fact that fluorescent molecules can be photobleached, i.e. they can be made irreversibly non-fluorescent by illuminating them at high excitation intensity. After selectively photobleaching a small volume within a larger volume, for instance within a living cell nucleus, the recovery of fluorescence due to movement (for instance by diffusion) of unbleached mobile molecules from outside the bleached region moving into the region is followed at regular time intervals. The extent to and rate at which this happens represent the fractions of mobile and immobile molecules and the speed at which they move. Since the precise quantitative analysis of the resulting FRAP curves is difficult, as discussed below, FRAP is especially powerful if the system under surveillance can be studied in an active and passive state, so that a difference in mobility can be attributed to protein function. For instance, in DNA repair, one can compare protein mobilities in unchallenged cells with those in cells that were exposed to a DNA damageinducing agent. In transcriptional regulatory systems, like the nuclear hormone receptors, one can compare mobilities of ligand-induced and inactive receptors such as either non-liganded receptors, receptors 
inhibited by antagonistic ligands or receptor mutants lacking DNA-binding properties (Farla et al. 2005). Such comparative studies can be based on qualitative analysis, i.e., visual inspection of the curves, or semiquantitative analysis, by calculating the half life of fluorescence recovery. In addition, a permanently immobilised fraction can be readily estimated from the incomplete recovery of fluorescence. Although this straightforward approach is by itself useful, as can be seen from the wealth of mechanistic insight that has been gained from many studies, half-lives (which are frequently reported) only provide information on overall mobility but do not allow detailed quantitative analysis. For example, when relatively small fractions of proteins are engaged in immobilising DNA-binding events, half-life will be only slightly increased compared to fully free protein. Therefore, half-life is not easily translated into quantitative estimates of bound fractions or residence times in immobile DNA-protein complexes.

To obtain more quantitative information from FRAP analysis, sophisticated analytical models have been established. The parameters that one aims to quantitatively assess are effective on- and off-rates to and from immobile DNA-protein complexes, which can be used to calculate the bound fraction and residence time in the complex, parameters that are usually reported. When on-rates increase at constant off-rate, the immobile fraction also increases. When off-rates increase, the immobile fraction becomes smaller at constant on-rate, and, in addition, the residence time becomes shorter. Apart from the parameters to be extracted from the FRAP curve, mathematical or numerical models essentially include a number of fixed parameters representing both microscopic properties, like shape, size and intensity profile of the laser beam focused by the objective lens, as well as properties of the nucleus like shape and size and the intranuclear distribution of the factors under surveillance. Most of these can be obtained experimentally in control measurements. However, incorporating them in mathematical models requires skilled mathematicians (Mueller et al. 2010). In the development of these models, therefore a number of simplifications have been applied. Initially it was frequently assumed that diffusion is in general so fast that it can be neglected in the FRAP model. The simplified models assumed reaction-dominant or diffusion-uncoupled FRAP recovery, where curves can be separated in an extremely short diffusive phase, essentially taking less than a second, and a much longer binding phase over a period of seconds to minutes (Sprague et al. 2004; Sprague and McNally 2005; Beaudouin et al. 2006). However, it was recently suggested that diffusion may also contribute to very slow FRAP recoveries, as long as the time to associate with a binding site is fast compared to diffusion (Mueller et al. 2008, 2010). If in these cases diffusion is neglected this may lead to the false prediction of an additional short-lived binding state. A proper procedure to verify whether FRAP recovery curves are diffusion coupled or uncoupled is by applying bleach pulse areas with increasing size. When diffusion is relatively fast, recovery is hardly affected by the size of the bleach area (Phair et al. 2004; Sprague et al. 2004).

In order to simplify mathematical models, the photobleached region is sometimes modelled as a cylindrical uniform profile (Carrero et al. 2003), or a cylindrical region with a radial Gaussian distribution (Braeckmans et al. 2003; Kang and Kenworthy 2008; Tsibidis and Ripoll 2008; Tsibidis 2009). However, although a cylindrical profile is justified when a low numerical aperature (NA) lens is used, a double-cone profile may be more accurate, even for low NA lenses (Braeckmans et al. 2007; van Royen et al. 2009; Hallen and Layton 2010). Furthermore, unlike a cylindrical bleaching profile, the double-cone profile also implies a significant dependency of the three dimensional situation, because of the axial Gaussian distribution of the laser beam (Mazza et al. 2007, 2008; Hallen and Layton 2010). These and other fixed parameters, like photophysical properties of the fluorophores in use (e.g. blinking and reversible photo-bleaching), and also experimental settings like the duration of bleaching and the consequences for diffusion during bleaching should be carefully considered in the development of a kinetic model (Braga et al. 2004; Mueller et al. 2008, 2010; Kang et al. 2009). Another complication in the development of mathematical models is a heterogeneous distribution of target sites of the labelled proteins. Most models assume a homogeneous distribution of binding sites, ignoring the typical spatial organisation of nuclear processes like gene transcription or DNA replication (Kang and Kenworthy 2008; Mueller et al. 2008). A more accurate binding model would then be one which takes the actual inhomogeneous distribution of 
binding sites into account by using the acquired imaging data (Beaudouin et al. 2006).

Although with the right interpretation, FRAP data are very informative about the mobility of fluorescently labelled proteins, it clearly has its limitations. The integration of complementary techniques like single-molecule tracking (SMT) and fluorescence correlation spectroscopy will be of great value in unravelling the full picture of the dynamic behaviour of proteins. These approaches will be discussed elsewhere in this issue (Erdel et al. 2011; Dange et al. 2011).

\section{How do nuclear proteins bind their targets?}

FRAP is very well suited to analyse the function and behaviour of proteins that exert their functions in DNA-protein complexes, since DNA or chromatin is essentially immobile over the time a typical FRAP experiment takes. Therefore, residence times in the immobile state determined by FRAP experiments reflect the engagement of the investigated factor in DNAprotein complexes. This enabled researchers even in the early days of live-cell imaging and GFP-tagging to observe surprisingly short-lived DNA-protein complexes in DNA repair of single-strand lesions (Houtsmuller et al. 1999) and transcription initiation (McNally et al. 2000). Following these pioneering studies, a large number of reports showed a similarly dynamic interaction of nuclear proteins with DNA, including investigations on gene transcription and RNA processing, DNA repair, DNA replication and chromatin structure (Kruhlak et al. 2000; Leonhardt et al. 2000; Mattern et al. 2004; Sporbert et al. 2002; Stavreva et al. 2004). In Fig. 3a, a comparison is made between the mobilities of a selection of proteins from these studies. In view of the difficulty to compare FRAP-data obtained by different procedures and analytical methods, as discussed above, we chose to present the time until complete recovery estimated from the published FRAP-curves since we think that in many cases these serve well as an indication of the actual residence times of the indicated proteins in DNAassociated complexes. We are aware, however, that this rough analysis only holds for proteins with effective on- and off-rates in the lower left part of Fig. $3 b$ and the left corner of the diamond in Fig. 3c. For proteins with higher on- and off-rates, residence times in immobile complexes will be substantially shorter (top right part in Fig. $3 b$, right corner in $3 c$ ). Note that this very frequent and transient binding behaviour is only possible when the concentration of binding sites is very high since proteins hardly have time to diffuse over longer distances between binding events, but no relatively long binding events occur. Typically, these are scenarios where DNA is constantly (aspecifically) bound, such as the hopping, sliding or jumping models discussed above. Obviously, prior knowledge of the function of the protein under surveillance may help to interpret FRAP curves in this way. For instance XPC, the damage sensor in nucleotide excision repair, likely interacts frequently and shortly with intact DNA, as argued above, leading to prolonged recovery times, in the order of tens of seconds, much longer than the actual aspecific DNA-binding time. However, in cells exposed to ultraviolet light, a substantial part of the XPC protein is much longer bound to immobile DNA damage, leading from a shift from the right to the left corner in Fig. 3c. In this case, recovery times are in the order of several minutes (Hoogstraten et al. 2008; Nishi et al. 2009) and can be used to roughly estimate DNAbinding times. In addition, in a number of cases, proteins interact with subnuclear structures like DNA repair foci, in which case final recovery time (of bleached foci) also is a good indicator of binding times.

In cases where proteins reside relatively long in the immobile fraction (either in foci, or scattered throughout the nucleus), like the DNA repair proteins, binding time estimated from recovery time, still largely depends on the assumed binding model (Figs. 3b and c, 4a). When simple binding kinetics are assumed (where the equilibrium between immobile and mobile state is determined by the ratio of on- and off-rates) residence times are distributed exponentially (red curve in Fig. 4b). In case the effective on- and off-rates are in the lower left panel of Fig. 3b, the characteristic binding time is approximately $1 / 5$ of the time until full recovery. However, a more complex binding model can be hypothesised, where the stability of the complex increases over time, due to entry of stabilising factors, and drops when the required action is performed. In this case, average residence times are more towards $1 / 2$ or $1 / 3$ of the time until full recovery (blue curve in Fig. 4b). Such a more complex binding model can be appreciated if for instance a DNA repair complex in progress is considered. It is conceivable that the damage sensing protein XPC is initially bound in a 
A

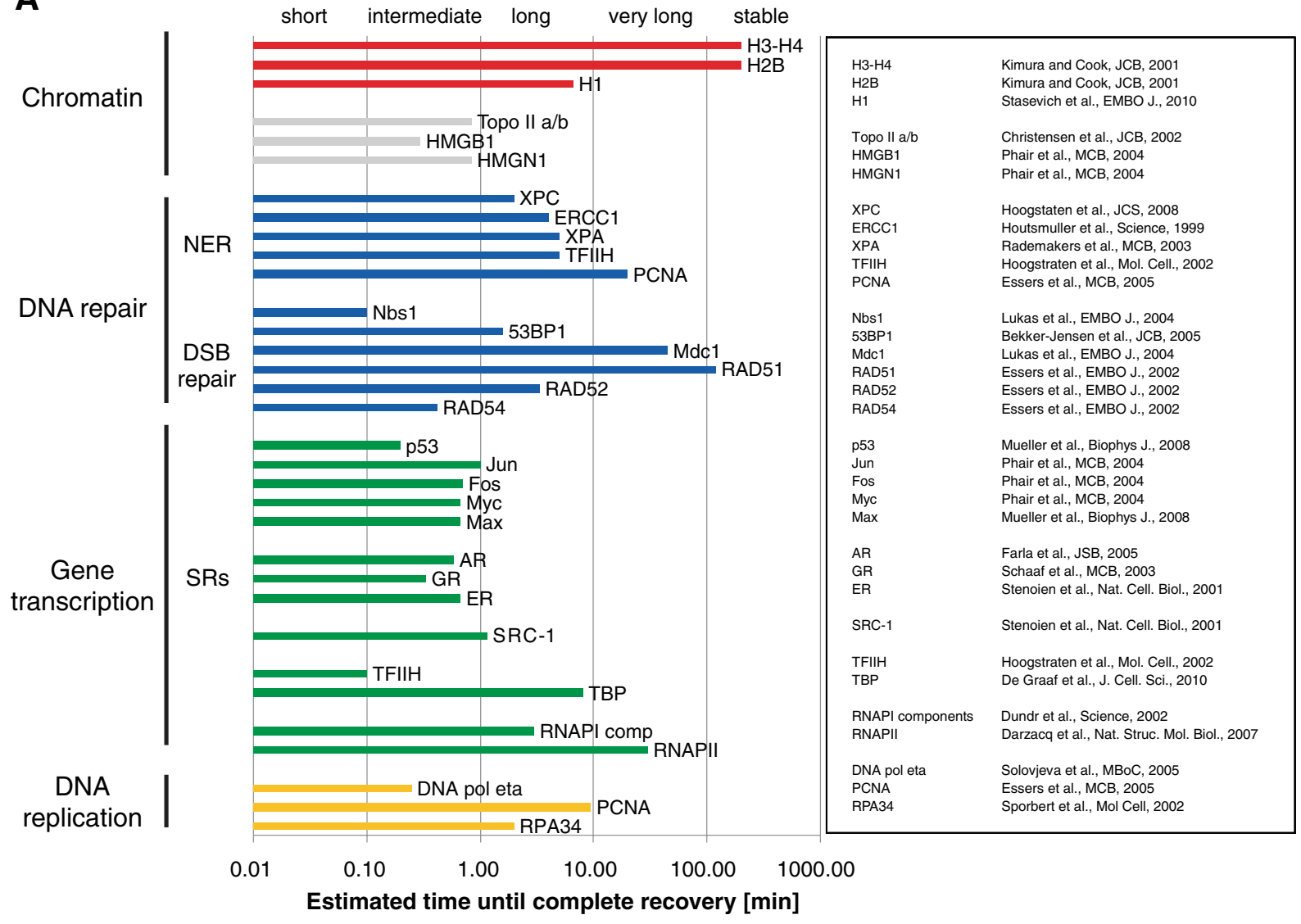

B

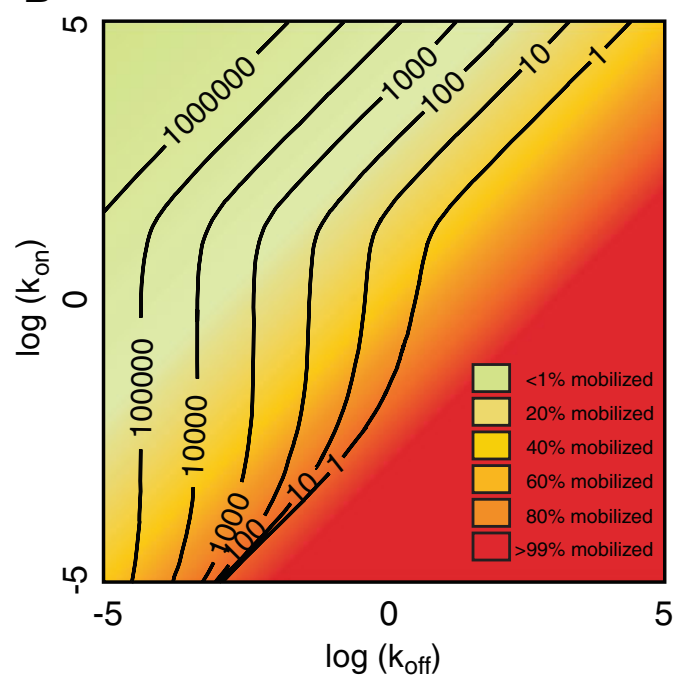

C

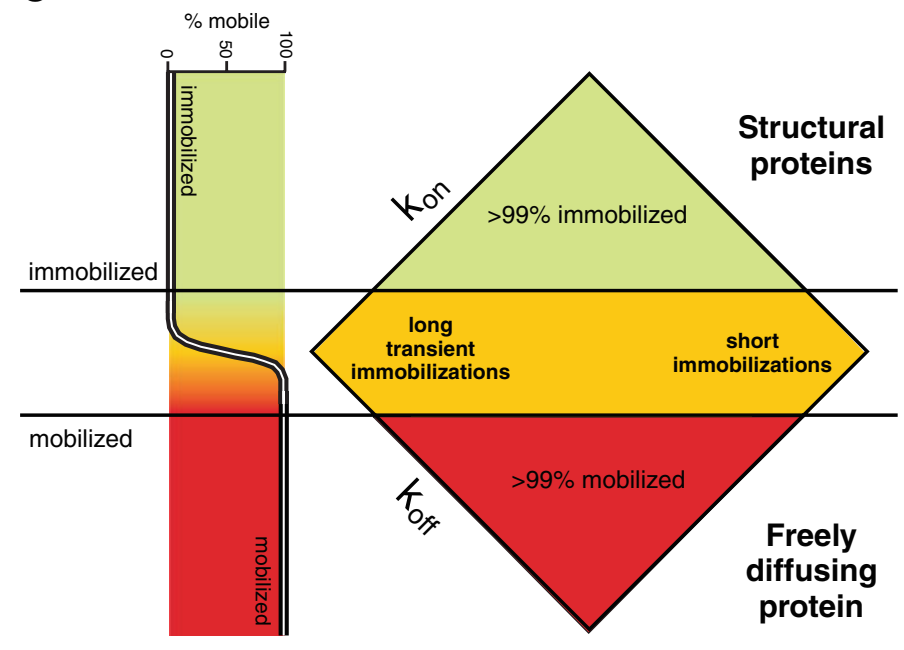

less-stable manner than when it is stabilised by binding of later factors (cf Fig. 2b; Mone et al. 2004; Dinant et al. 2009; Nishi et al. 2009). In addition, when repair is finished, off-rates of involved proteins will consider- ably increase, leading to their rapid release. Similarly, in transcriptional regulation, many types of mediator and chromatin remodelling complexes are involved, which may have a role in stabilising initial promoter 
Fig. 3 Relationship between time until final recovery in FRAP experiments and residence time in immobile complexes. a Time until complete recovery in FRAP experiments of a selection of nuclear proteins involved in several nuclear functions $(\log$ plot). Note that repair factors are measured in the presence of induced DNA damage and they in general show longer recovery times than transcription factors. b and c Diagrams adapted from Sprague et al. 2004, showing the relationship between on/off ratio ( $\mathrm{y}$ - and $\mathrm{x}$-axes respectively), immobile fraction (colour coding) and time until final recovery (solid lines) (note that in both curves, $\mathrm{K}_{\mathrm{on}}$ defines effective on-rate, which is independent of concentration)

binding of founding factors, such as steroid receptors (McKenna et al. 1999; Hermanson et al. 2002; Smith and O’Malley 2004; Heemers and Tindall 2007). Moreover, transcription complexes have been suggested to be actively disassembled by chaperone proteins, in which case effective off-rate increases dramatically (Elbi et al. 2004). Such scenarios, where early factors undergo more changes in binding stability than late binding factors, or where factors are actively released after finishing their job, give rise to different distributions of binding times (Fig. 4b), but surprisingly similar FRAP-curves (Fig. 4c).

While the above studies clearly show the dynamic interplay between DNA-binding proteins and chromatin in general, there are still a number of questions that remain to be discussed for individual proteins: Do proteins associate with target DNA or DNA-protein complexes until, for instance, repair is completed or transcription is initiated, or do they stay shorter, only to perform their own specific task within the entire process? Do unproductive binding events also occur, and if yes how often? In addition, is there a specific or preferred order in which factors assemble? Below we discuss these issues in detail.
Fig. 4 DNA-binding models. a The top cartoon shows a simple binding model which gives rise to an exponential distribution of binding times (red curve in b). In a more complex model, early binding factors have different binding kinetics (blue curve in b) since the complex is stabilised when later factors bind resulting in a lower off-rate. b Frequency distributions of residence times for the complex (blue) and simple (red) binding model.

Average binding time in the simple model is $30 \mathrm{~s}$ and in the complex model $50 \mathrm{~s}$. c FRAP-curves generated by Monte Carlo simulation of the complex (blue) and simple (red) binding model are very similar, in spite of the large difference in average residence times

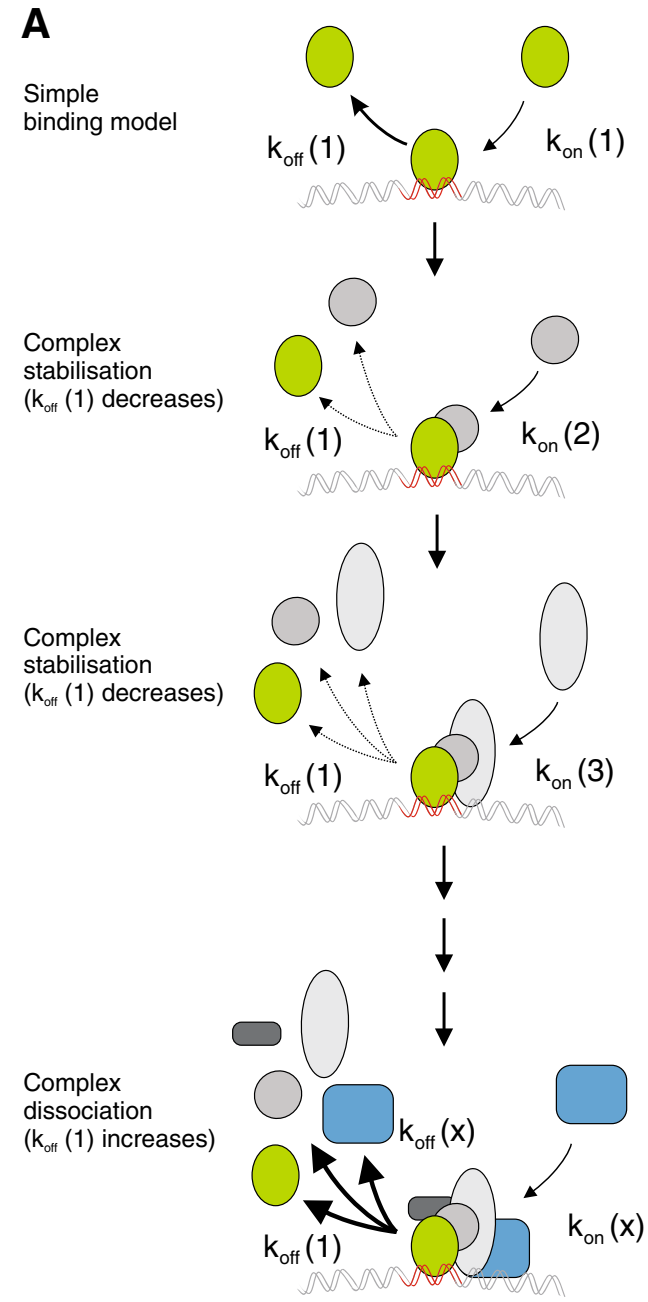

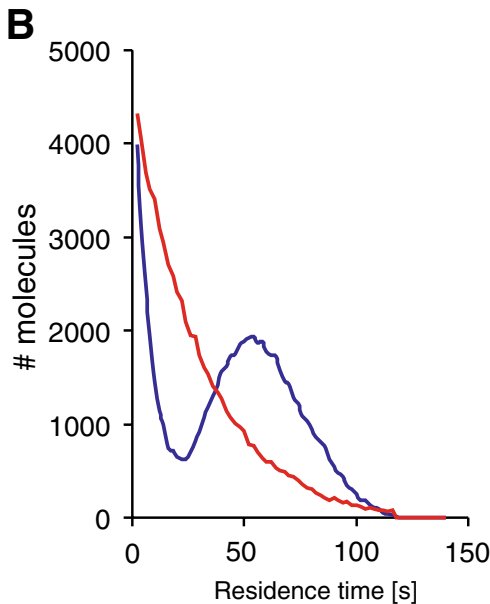

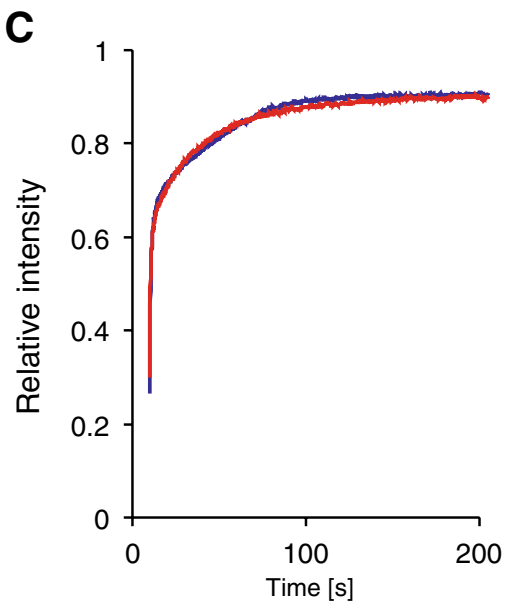


Results from FRAP-studies on single-strand DNAdamage by nucleotide excision repair (NER) point to an action mechanism where repair factors are present in DNA-protein complexes for the time required to repair a single lesion, and leave the spot soon after. First, all investigated NER constituents, including ERCC1/XPF (Houtsmuller et al. 1999), XPB (Hoogstraten et al. 2002), XPA (Rademakers et al. 2003), XPC (Hoogstraten et al. 2008; Nishi et al. 2009) and XPG (Zotter et al. 2006) have similar and relatively long fluorescence recovery times in the order of 3 to $5 \mathrm{~min}$, and show similar immobile fractions, dependent on the number of lesions present. Second, the time it takes to fully repair all single-strand lesions induced by UVirradiation at $8 \mathrm{~J} / \mathrm{m}^{2}$ predicted on the basis these FRAP measurements is in agreement with the total repair time determined by incorporation of labelled nucleotides at different time points after damage induction (Houtsmuller et al. 1999). A different picture arises from studies on double-strand break repair (DSB) dynamics, where residence times of individual factors in DSB foci differ considerably from each other (e.g. RAD54, $\sim 3 \mathrm{~s}$; RAD52, $\sim 5 \mathrm{~min}$; and RAD51, stably bound, see Fig. 3a), and are mostly much shorter than the life span of individual DSB foci, which is in the order of several hours. An interesting, but highly speculative explanation for the observed very rapid interactions of RAD54 is related to its ability to hydrolyse ATP in a DSB-dependent manner (Swagemakers et al. 1998). If its main activity in DSB foci would be hydrolysing ATP, it may be that during each short-term visit RAD54 delivers a small amount of energy by hydrolysing a few ATPs, thereby fuelling the ongoing repair process. In contrast, RAD51, which is very stably associated to DSB foci, may have a scaffolding function. Thus, opposite to the situation in NER, in DSB repair, individual factors do not reside in a DSB focus during its entire life span, but in general have shorter residence times, which may correspond to the time required to perform specific actions within the entire repair process. In transcription, the situation is probably more complex, where different models may explain consecutive steps, from initial binding by regulatory factors such as steroid receptors and cofactors, which may act similarly to NER factors (see also below), followed by assembly of the general transcription machinery and finalised by launching of RNA polymerase II. The general transcription complex may behave more similarly to the DSB repair system, in a sense that residence times differ considerably between individual factors, where the TATA-boxbinding protein TBP as a part of TFIID shows relatively long residence times, in the order of tens of minutes (de Graaf et al. 2010), whereas residence times of TFIIH are in the order of several seconds rather than minutes (Hoogstraten et al. 2002). A speculative explanation of the long-term binding of TBP, may be in the observation that its residence times are influenced by the presence or absence of coactivators or repressors, where the latter increase its binding times, suggesting a regulatory role for TBP in addition to its function in initiation (de Graaf et al. 2010). The very rapid interactions of TFIIH in transcription are in contrast with its behaviour in single-strand damage repair, where it is engaged in repair complexes for minutes (Hoogstraten et al. 2002). Interestingly, not only TFIIH, but repair factors in general seem to be more stably associated with repair complexes than transcription factors are with transcription initiation complexes (Fig. 3a). An attractive explanation for this could be that DNA damage demands urgent removal, and is stably bound by repair complexes, whereas transcription (regulation) is an ongoing process, possibly requiring less tight attention. In other words, repair factors better do their job properly, whereas transcription factors may miss a round or two.

Next to these speculative considerations, it should be noted also that it is highly likely, given the increasingly recognised stochastic nature of all molecular behaviour in the cell, that not all observed binding events are actually productive. Very transient interactions in the subsecond range have been reported to occur on a large scale, together with longer binding events. For instance in DNA replication and in AR-regulated transcription, experimental FRAP curves fit best to curves generated by Monte Carlo computer simulations of a scenario where in addition to relatively long binding events, the majority of the proteins are binding transiently to DNA (Xouri et al. 2007; Tanner et al. 2010). These interactions may also contribute to the observed anomalous diffusion discussed above and may represent aspecific binding events, possibly leading to sliding along DNA.

FRAP has been instrumental in determining residence times in DNA-protein complexes, but other approaches have been explored to address the question whether individual factors bind in a preferred 
or specific order to the complexes in progress. Obviously, factors that identify targets in chromatin, like transcription regulatory factors or DNA damage sensors are early binders, but less knowledge exists on the order, if any, in which the subsequent activities bind (Dinant et al. 2009; Coulon et al. 2010). In DNA repair of single-strand lesions it was shown that in patient or mutant cell lines, each lacking a specific factor, only a subset of the other repair proteins would assemble on a locally induced damage spot within the nucleus. These data suggest a defined order of binding, where the single-strand lesion is first detected then stabilised, unwound, cut out and resynthesised. Along the same lines, but exploring an alternative approach where they used ionising irradiation of a limited volume in the nucleus, and followed the assembly of several GFP-tagged DSB repair-proteins, ample evidence has been provided that these factors assemble in a specific order (Jazayeri et al. 2006; Essers et al. 2006). After IRinduced DNA damage, activated ATM binds Chk2 very transiently resulting in activation and Chk2mediated cell cycle arrest (Lukas et al. 2003, 2004). This very transient binding is contrasted by the binding of the Mre11-Rad50-Nbs1 complex (MRN) at the damage site, which is followed by consecutive binding of RPA, ATR, Chk1 and the RAD52-group proteins and others (Jazayeri et al. 2006). During the existence of the holocomplex, the involved factors dynamically exchange between the complex and the nucleoplasm, each factor having its own average residence time (Essers et al. 2005).

In an experimentally different set-up, chromatin immunoprecipitation (ChIP) experiments on cultured synchronised cells suggest a cyclic binding pattern in hormone-regulated transcription, where estrogen receptors (ERs), cofactors and finally the general transcription machinery bind in a more or less defined order, and release soon after transcription initiation, leaving the gene for a new round of binding (Metivier et al. 2003). Since the observed cycles were typically in the order of tens of minutes these data initiated discussion on the interpretation of many of the preceding FRAP experiments on nuclear receptors which suggested a much shorter binding time in the order of tens of seconds rather than minutes (e.g. McNally et al. 2000; Farla et al. 2004, 2005; Schaaf and Cidlowski 2003; Rayasam et al. 2005; Marcelli et al. 2006; Klokk et al. 2007; Meijsing et al. 2007).
However, an explanation for the apparent inconsistency of ChIP and FRAP data was provided by McNally and co-workers who showed, combining FRAP and single-cell measurements of messenger RNA, that rapid exchange of the yeast copperinducible transcription factor ACE1p with each copy of an array of endogenous CUP1 promoters occurs, but that the number of available binding sites in the array goes through cycles on a longer time scale in the order of tens of minutes (Karpova et al. 2008). This indicates that during the existence of a productive complex, individual components may continually exchange, similar to RAD54 in DSB repair. Indeed, such exchange has been observed for histones, of which the exchange is increased in transcriptionally active areas, but also occurs in other areas (Kimura et al. 2002).

The combination of acceptor photobleaching FRET and FRAP has provided an alternative approach to investigate binding order. In this method, the increase and the subsequent loss of fluorescence of FRET-donor fluorescence in a small region inside the nucleus after photobleaching the FRET-acceptor, is compared with the recovery of FRET-acceptor fluorescence (van Royen et al. 2007). Application of this approach to androgen receptors double tagged with the FRET-pair CFP and YFP at the $\mathrm{N}$ and $\mathrm{C}$ terminuses, revealed that androgen receptors undergo a transformational change after binding to regulatory regions of androgen-regulated genes, and that this change uncovers binding sites for cofactors allowing them to bind to the same regions only after ARs have bound.

Apart from binding in a specific order, it has also been shown that different factors influence, i.e. stimulate or inhibit, each others binding behaviour. For example, the glucocorticoid receptor and highmobility group box protein 1 interact when bound to chromatin and decrease each others' mobility (Agresti et al. 2005), suggesting a cooperative binding mechanism. Another example of cooperative binding behaviour is provided by detailed analysis of the dynamic behaviour of linker histone H1. Sophisticated FRAP analysis of various GFP-tagged truncated H1 variants each harbouring defined DNA-binding domains revealed two distinct binding mechanisms through different combinations of domains and an additional metastable intermediate binding state (Stasevich et al. 2010). These types of cooperative binding reactions cannot be described by a simple binding reaction 
model, but require a model of sequential binding events or even more complex models that includes initial complex formation (cf. Fig. 4) (Mueller et al. 2010). Most likely these complex binding events will lead to more variability in its binding kinetics and in particular a varying off-rate.

\section{Conclusion}

We have discussed models and supportive data concerning mechanisms by which nuclear proteins translocate to their target sites, and how they interact with DNA or DNA-protein complexes. Taking together the results of various approaches, the predominant mechanism by which proteins travel through the nucleus to find their target sites is one of three-dimensional diffusion. It is however, not yet clear how nuclear factors find the precise nucleotide sequence or DNA damage in the vast amount of DNA. It has been argued that DNA-scanning mechanisms should exist (1D diffusion), enhancing the chance to encounter a target site (Fig. 1a). Indeed it can be calculated that a specific molecule that effectively diffuses at a typical rate of say $1 \mu \mathrm{m}^{2} / \mathrm{s}$ in a (large) nucleus with a diameter of say $30 \mu \mathrm{m}$, will collide with for instance a nucleosome with a diameter of $10 \mathrm{~nm}$ only once a day. In contrast to this, it can also be argued that, from the viewpoint of a specific binding site awaiting a factor to bind, it is not relevant which of the often thousands or tens of thousands of copies actually binds, which will happen several times per minute. In addition, many nuclear proteins that do not bind DNA directly, may not have intrinsic DNA-binding properties, and may not be able to explore DNA-scanning mechanisms to enhance their binding chances. However, since the investigated endonuclease and other DNA-binding proteins are clearly able to slide along DNA in vitro, it seems likely that at least short stretches of DNA are scanned continually by DNA-interacting factors in vivo, enhancing their binding efficiency. Sliding mechanisms in that view can then be regarded as binding mechanisms rather than finding mechanisms, similar to protein-protein interactions that often start with weak interactions, after which strong interactions are initiated by reorientation of the binding partners. As an alternative to 1D-diffusion, hopping or jumping models have been suggested. However, these hopping events (Fig. 1c) also occur frequently in a model of free diffusion and random collision. It may be that the recently reported fractal organisation of chromatin facilitates hopping behaviour (Bancaud et al. 2009; Lieberman-Aiden et al. 2009). However, further investigation is required to verify whether binding and rebinding of factors for instance in chromatin areas rich in binding sites occurs more frequently than expected on the basis of free diffusion.

In Fig. 3 we provided a semi-quantitative comparison of nuclear proteins involved in several nuclear processes, which allows to make general statements about the large scale differences between residence times of different factors in DNA-protein complexes. Although our interpretations are highly speculative and require much more research, we discussed the possible relationship between the observed residence times and protein function. Moreover, apart from the fact that data are compared from different labs using different FRAP approaches and analytical methods, which we tried to overcome by showing final recovery times (Fig. 3a), the influence of the GFPtag on a labelled protein may limit to some extent the validity of our comparison. Although GFP-tagged proteins are in general thoroughly tested to be functional in spite of the bulky tag, it would be overly optimistic to assume that there is no influence. Since the potentially limiting effect on function is likely to differ between different proteins, caution is required, especially when precise quantitative data are integrated in systems biology approaches to present a full quantitative model.

Finally, quantitative fluorescence methods, specifically FRAP, and other approaches have revealed a highly dynamic behaviour of nuclear proteins, but to fully unravel the reaction mechanisms by which DNAprotein complexes perform their functions, more research and the application of novel approaches are required. In the field of fluorescence, single-molecule tracking and high-resolution microscopy technology are expected to play an important role in this further research.

\section{References}

Adam G, Delbruck M (1968) Reduction of dimensionality in biological diffusion processes. Nature Publishing Group, Struct Chem Mol Biol. pp 198-215 
Agresti A, Scaffidi P, Riva A, Caiolfa VR, Bianchi ME (2005) GR and HMGB1 interact only within chromatin and influence each other's residence time. Mol Cell 18:109121

Bancaud A, Huet S, Daigle N, Mozziconacci J, Beaudouin J, Ellenberg J (2009) Molecular crowding affects diffusion and binding of nuclear proteins in heterochromatin and reveals the fractal organization of chromatin. EMBO $\mathrm{J}$ 28:3785-3798

Beaudouin J, Mora-Bermudez F, Klee T, Daigle N, Ellenberg J (2006) Dissecting the contribution of diffusion and interactions to the mobility of nuclear proteins. Biophys J 90:1878-1894

Bekker-Jensen S, Lukas C, Melander F, Bartek J, Lukas J (2005) Dynamic assembly and sustained retention of 53BP1 at the sites of DNA damage are controlled by Mdc1/NFBD1. J Cell Biol 170:201-211

Bellomy GR, Record MT Jr (1990) Stable DNA loops in vivo and in vitro: roles in gene regulation at a distance and in biophysical characterization of DNA. Prog Nucleic Acid Res Mol Biol 39:81-128

Berg OG, Winter RB, von Hippel PH (1981) Diffusion-driven mechanisms of protein translocation on nucleic acids. 1 . Models and theory. Biochemistry 20:6929-6948

Blainey PC, van Oijen AM, Banerjee A, Verdine GL, Xie XS (2006) A base-excision DNA-repair protein finds intrahelical lesion bases by fast sliding in contact with DNA. Proc Natl Acad Sci USA 103:5752-5757

Blainey PC, Luo G, Kou SC, Mangel WF, Verdine GL, Bagchi B, Xie XS (2009) Nonspecifically bound proteins spin while diffusing along DNA. Nat Struct Mol Biol 16:12241229

Braeckmans K, Peeters L, Sanders NN, De Smedt SC, Demeester J (2003) Three-dimensional fluorescence recovery after photobleaching with the confocal scanning laser microscope. Biophys J 85:2240-2252

Braeckmans K, Remaut K, Vandenbroucke RE, Lucas B, De Smedt SC, Demeester J (2007) Line FRAP with the confocal laser scanning microscope for diffusion measurements in small regions of 3-D samples. Biophys J 92:2172-2183

Braga J, Desterro JM, Carmo-Fonseca M (2004) Intracellular macromolecular mobility measured by fluorescence recovery after photobleaching with confocal laser scanning microscopes. Mol Biol Cell 15:4749-4760

Carrero G, McDonald D, Crawford E, de Vries G, Hendzel MJ (2003) Using FRAP and mathematical modeling to determine the in vivo kinetics of nuclear proteins. Methods 29:14-28

Christensen MO, Larsen MK, Barthelmes HU, Hock R, Andersen CL, Kjeldsen E, Knudsen BR, Westergaard O, Boege F, Mielke C (2002) Dynamics of human DNA topoisomerases II $\{$ alpha $\}$ and II $\{$ beta $\}$ in living cells. J Cell Biol 157:31-44

Coulon A, Gandrillon O, Beslon G (2010) On the spontaneous stochastic dynamics of a single gene: complexity of the molecular interplay at the promoter. BMC Syst Biol 4:2

Dange T, Joseph A, Grünwald D (2011) A perspective of the dynamic structure of the nucleus explored at the singlemolecule level. Chromosome Res. doi:10.1007/s10577010-9156-5
Darzacq X, Shav-Tal Y, de Turris V, Brody Y, Shenoy SM, Phair RD, Singer RH (2007) In vivo dynamics of RNA polymerase II transcription. Nat Struct Mol Biol 14:796-806

de Graaf P, Mousson F, Geverts B, Scheer E, Tora L, Houtsmuller AB, Timmers HTM (2010) Chromatin interaction of TATA-binding protein is dynamically regulated in human cells. J Cell Sci 123:2663-2671

Dinant C, Luijsterburg MS, Hofer T, von Bornstaedt G, Vermeulen W, Houtsmuller AB, van Driel R (2009) Assembly of multiprotein complexes that control genome function. J Cell Biol 185:21-26

Dundr M, Hoffmann-Rohrer U, Hu Q, Grummt I, Rothblum LI, Phair RD, Misteli T (2002) A kinetic framework for a mammalian RNA polymerase in vivo. Science 298:16231626

Elbi C, Walker DA, Romero G, Sullivan WP, Toft DO, Hager GL, DeFranco DB (2004) Molecular chaperones function as steroid receptor nuclear mobility factors. Proc Natl Acad Sci USA 101:2876-2881

Elf J, Li GW, Xie XS (2007) Probing transcription factor dynamics at the single-molecule level in a living cell. Science 316:1191-1194

Erdel F, Müller-Ott K, Baum M, Wachsmuth M, Rippe K (2011) Dissecting chromatin interactions in living cells from protein mobility maps. Chromosome Res. doi:10.1007/s10577-0109155-6

Essers J, Houtsmuller AB, van Veelen L, Paulusma C, Nigg AL, Pastink A, Vermeulen W, Hoeijmakers JH, Kanaar R (2002) Nuclear dynamics of RAD52 group homologous recombination proteins in response to DNA damage. EMBO J 21:2030-2037

Essers J, Theil AF, Baldeyron C, van Cappellen WA, Houtsmuller AB, Kanaar R, Vermeulen W (2005) Nuclear dynamics of PCNA in DNA replication and repair. Mol Cell Biol 25:9350-9359

Essers J, Vermeulen W, Houtsmuller AB (2006) DNA damage repair: anytime, anywhere? Curr Opin Cell Biol 18:240 246

Farla P, Hersmus R, Geverts B, Mari PO, Nigg AL, Dubbink HJ, Trapman J, Houtsmuller AB (2004) The androgen receptor ligand-binding domain stabilizes DNA binding in living cells. J Struct Biol 147:50-61

Farla P, Hersmus R, Trapman J, Houtsmuller AB (2005) Antiandrogens prevent stable DNA-binding of the androgen receptor. J Cell Sci 118:4187-4198

Gerland U, Moroz JD, Hwa T (2002) Physical constraints and functional characteristics of transcription factorDNA interaction. Proc Natl Acad Sci USA 99:1201512020

Gorisch SM, Richter K, Scheuermann MO, Herrmann H, Lichter P (2003) Diffusion-limited compartmentalization of mammalian cell nuclei assessed by microinjected macromolecules. Exp Cell Res 289:282-294

Gorisch SM, Wachsmuth M, Toth KF, Lichter P, Rippe K (2005) Histone acetylation increases chromatin accessibility. J Cell Sci 118:5825-5834

Gorman J, Greene EC (2008) Visualizing one-dimensional diffusion of proteins along DNA. Nat Struct Mol Biol 15:768-774

Gorman J, Chowdhury A, Surtees JA, Shimada J, Reichman DR, Alani E, Greene EC (2007) Dynamic basis for one- 
dimensional DNA scanning by the mismatch repair complex Msh2-Msh6. Mol Cell 28:359-370

Gowers DM, Wilson GG, Halford SE (2005) Measurement of the contributions of $1 \mathrm{D}$ and $3 \mathrm{D}$ pathways to the translocation of a protein along DNA. Proc Natl Acad Sci USA 102:15883-15888

Graneli A, Yeykal CC, Robertson RB, Greene EC (2006) Longdistance lateral diffusion of human Rad51 on doublestranded DNA. Proc Natl Acad Sci USA 103:1221-1226

Halford SE, Marko JF (2004) How do site-specific DNA-binding proteins find their targets? Nucleic Acids Res 32:3040-3052

Hallen MA, Layton AT (2010) Expanding the scope of quantitative FRAP analysis. J Theor Biol 262:295-305

Harada Y, Funatsu T, Murakami K, Nonoyama Y, Ishihama A, Yanagida T (1999) Single-molecule imaging of RNA polymerase-DNA interactions in real time. Biophys $\mathrm{J}$ 76:709-715

Heemers HV, Tindall DJ (2007) Androgen receptor (AR) coregulators: a diversity of functions converging on and regulating the AR transcriptional complex. Endocr Rev 28:778-808

Hermanson O, Glass CK, Rosenfeld MG (2002) Nuclear receptor coregulators: multiple modes of modification. Trends Endocrinol Metab 13:55-60

Hoogstraten D, Nigg AL, Heath H, Mullenders LH, van Driel R, Hoeijmakers JH, Vermeulen W, Houtsmuller AB (2002) Rapid switching of TFIIH between RNA polymerase I and II transcription and DNA repair in vivo. Mol Cell 10:1163-1174

Hoogstraten D, Bergink S, Ng JM, Verbiest VH, Luijsterburg MS, Geverts B, Raams A, Dinant C, Hoeijmakers JH, Vermeulen W, Houtsmuller AB (2008) Versatile DNA damage detection by the global genome nucleotide excision repair protein XPC. J Cell Sci 121:2850-2859

Houtsmuller AB, Rademakers S, Nigg AL, Hoogstraten D, Hoeijmakers JH, Vermeulen W (1999) Action of DNA repair endonuclease ERCC1/XPF in living cells. Science 284:958-961

Jack WE, Terry BJ, Modrich P (1982) Involvement of outside DNA sequences in the major kinetic path by which EcoRI endonuclease locates and leaves its recognition sequence. Proc Natl Acad Sci USA 79:4010-4014

Jazayeri A, Falck J, Lukas C, Bartek J, Smith GCM, Lukas J, Jackson SP (2006) ATM- and cell cycle-dependent regulation of ATR in response to DNA double-strand breaks. Nat Cell Biol 8:37-45

Jeltsch A, Pingoud A (1998) Kinetic characterization of linear diffusion of the restriction endonuclease EcoRV on DNA. Biochemistry 37:2160-2169

Jeltsch A, Alves J, Wolfes H, Maass G, Pingoud A (1994) Pausing of the restriction endonuclease EcoRI during linear diffusion on DNA. Biochemistry 33:10215-10219

Jeltsch A, Wenz C, Stahl F, Pingoud A (1996) Linear diffusion of the restriction endonuclease EcoRV on DNA is essential for the in vivo function of the enzyme. EMBO J 15:5104-5111

Kabata H, Kurosawa O, Arai I, Washizu M, Margarson SA, Glass RE, Shimamoto N (1993) Visualization of single molecules of RNA polymerase sliding along DNA. Science 262:1561-1563

Kampmann M (2004) Obstacle bypass in protein motion along DNA by two-dimensional rather than one-dimensional sliding. J Biol Chem 279:38715-38720
Kang M, Kenworthy AK (2008) A closed-form analytic expression for FRAP formula for the binding diffusion model. Biophys J 95:L13-L15

Kang M, Day CA, Drake K, Kenworthy AK, DiBenedetto E (2009) A generalization of theory for two-dimensional fluorescence recovery after photobleaching applicable to confocal laser scanning microscopes. Biophys J 97:1501-1511

Karpova TS, Kim MJ, Spriet C, Nalley K, Stasevich TJ, Kherrouche Z, Heliot L, McNally JG (2008) Concurrent fast and slow cycling of a transcriptional activator at an endogenous promoter. Science 319:466-469

Kimura H, Cook PR (2001) Kinetics of core histones in living human cells: little exchange of $\mathrm{H} 3$ and $\mathrm{H} 4$ and some rapid exchange of H2B. J Cell Biol 153:1341-1353

Kimura H, Sugaya K, Cook PR (2002) The transcription cycle of RNA polymerase II in living cells. J Cell Biol 159:777-782

Klokk TI, Kurys P, Elbi C, Nagaich AK, Hendarwanto A, Slagsvold T, Chang C-Y, Hager GL, Saatcioglu F (2007) Ligand-specific dynamics of the androgen receptor at its response element in living cells. Mol Cell Biol 27:1823-1843

Kruhlak MJ, Lever MA, Fischle W, Verdin E, Bazett-Jones DP, Hendzel MJ (2000) Reduced mobility of the alternate splicing factor (ASF) through the nucleoplasm and steady state speckle compartments. J Cell Biol 150:41-52

Langowaski J, Alves J, Pingoud A, Maass G (1983) Does the specific recongnition of DNA by the restriction endonuclease EcoRI involve a linear diffusion step? Investigation of the processivity of the EcoRI endonuclease. Nucl Acids Res 11:501-513

Leonhardt H, Rahn H-P, Weinzierl P, Sporbert A, Cremer T, Zink D, Cardoso MC (2000) Dynamics of DNA replication factories in living cells. J Cell Biol 149:271-280

Lieberman-Aiden E, van Berkum NL, Williams L, Imakaev M, Ragoczy T, Telling A, Amit I, Lajoie BR, Sabo PJ, Dorschner MO, Sandstrom R, Bernstein B, Bender MA, Groudine M, Gnirke A, Stamatoyannopoulos J, Mirny LA, Lander ES, Dekker J (2009) Comprehensive mapping of long-range interactions reveals folding principles of the human genome. Science 326:289-293

Lomholt MA, van den Broek B, Kalisch SM, Wuite GJ, Metzler R (2009) Facilitated diffusion with DNA coiling. Proc Natl Acad Sci USA 106:8204-8208

Lukas C, Falck J, Bartkova J, Bartek J, Lukas J (2003) Distinct spatiotemporal dynamics of mammalian checkpoint regulators induced by DNA damage. Nat Cell Biol 5:255-260

Lukas C, Melander F, Stucki M, Falck J, Bekker-Jensen S, Goldberg M, Lerenthal Y, Jackson S, Bartek J, Lukas J (2004) Mdc1 couples DNA double-strand break recognition by Nbs 1 with its $\mathrm{H} 2 \mathrm{AX}$-dependent chromatin retention. EMBO J 23:2674-2683

Marcelli M, Stenoien DL, Szafran AT, Simeoni S, Agoulnik IU, Weigel NL, Moran T, Mikic I, Price JH, Mancini MA (2006) Quantifying effects of ligands on androgen receptor nuclear translocation, intranuclear dynamics, and solubility. J Cell Biochem 98:770-788

Mattern KA, Swiggers SJJ, Nigg AL, Lowenberg B, Houtsmuller AB, Zijlmans JMJM (2004) Dynamics of protein binding to telomeres in living cells: implications for telomere structure and function. Mol Cell Biol 24:5587-5594

Mazza D, Cella F, Vicidomini G, Krol S, Diaspro A (2007) Role of three-dimensional bleach distribution in confocal 
and two-photon fluorescence recovery after photobleaching experiments. Appl Opt 46:7401-7411

Mazza D, Braeckmans K, Cella F, Testa I, Vercauteren D, Demeester J, De Smedt SS, Diaspro A (2008) A new FRAP/FRAPa method for three-dimensional diffusion measurements based on multiphoton excitation microscopy. Biophys J 95:3457-3469

McKenna NJ, Xu J, Nawaz Z, Tsai SY, Tsai MJ, O’Malley BW (1999) Nuclear receptor coactivators: multiple enzymes, multiple complexes, multiple functions. J Steroid Biochem Mol Biol 69:3-12

McNally JG, Mazza D (2010) Fractal geometry in the nucleus. EMBO J 29:2-3

McNally JG, Muller WG, Walker D, Wolford R, Hager GL (2000) The glucocorticoid receptor: rapid exchange with regulatory sites in living cells. Science 287:1262-1265

Meijsing SH, Elbi C, Luecke HF, Hager GL, Yamamoto KR (2007) The ligand binding domain controls glucocorticoid receptor dynamics independent of ligand release. Mol Cell Biol 27:2442-2451

Metivier R, Penot G, Hubner MR, Reid G, Brand H, Kos M, Gannon F (2003) Estrogen receptor-alpha directs ordered, cyclical, and combinatorial recruitment of cofactors on a natural target promoter. Cell 115:751-763

Mone MJ, Bernas T, Dinant C, Goedvree FA, Manders EM, Volker M, Houtsmuller AB, Hoeijmakers JH, Vermeulen W, van Driel R (2004) In vivo dynamics of chromatin-associated complex formation in mammalian nucleotide excision repair. Proc Natl Acad Sci USA 101:15933-15937

Mueller F, Wach P, McNally JG (2008) Evidence for a common mode of transcription factor interaction with chromatin as revealed by improved quantitative fluorescence recovery after photobleaching. Biophys J 94:3323-3339

Mueller F, Mazza D, Stasevich TJ, McNally JG (2010) FRAP and kinetic modeling in the analysis of nuclear protein dynamics: what do we really know? Curr Opin Cell Biol 22:403-411

Nishi R, Alekseev S, Dinant C, Hoogstraten D, Houtsmuller AB, Hoeijmakers JH, Vermeulen W, Hanaoka F, Sugasawa K (2009) UV-DDB-dependent regulation of nucleotide excision repair kinetics in living cells. DNA Repair (Amst) 8:767-776

Phair RD, Misteli T (2000) High mobility of proteins in the mammalian cell nucleus. Nature 404:604-609

Phair RD, Scaffidi P, Elbi C, Vecerova J, Dey A, Ozato K, Brown DT, Hager G, Bustin M, Misteli T (2004) Global nature of dynamic protein-chromatin interactions in vivo: threedimensional genome scanning and dynamic interaction networks of chromatin proteins. Mol Cell Biol 24:6393-6402

Rademakers S, Volker M, Hoogstraten D, Nigg AL, Mone MJ, Van Zeeland AA, Hoeijmakers JH, Houtsmuller AB, Vermeulen W (2003) Xeroderma pigmentosum group A protein loads as a separate factor onto DNA lesions. Mol Cell Biol 23:5755-5767

Rayasam GV, Elbi C, Walker DA, Wolford R, Fletcher TM, Edwards DP, Hager GL (2005) Ligand-specific dynamics of the progesterone receptor in living cells and during chromatin remodeling in vitro. Mol Cell Biol 25:24062418

Sakata-Sogawa K, Shimamoto N (2004) RNA polymerase can track a DNA groove during promoter search. Proc Natl Acad Sci USA 101:14731-14735
Schaaf MJ, Cidlowski JA (2003) Molecular determinants of glucocorticoid receptor mobility in living cells: the importance of ligand affinity. Mol Cell Biol 23:1922-1934

Schurr JM (1975) The one-dimensional diffusion coefficient of proteins absorbed on DNA hydrodynamic considerations. Biophys Chem 9:413-414

Shimamoto N (1999) One-dimensional diffusion of proteins along DNA. Its biological and chemical significance revealed by single-molecule measurements. J Biol Chem 274:15293-15296

Smith CL, O'Malley BW (2004) Coregulator function: a key to understanding tissue specificity of selective receptor modulators. Endocr Rev 25:45-71

Solovjeva L, Svetlova M, Sasina L, Tanaka K, Saijo M, Nazarov I, Bradbury M, Tomilin N (2005) High mobility of flap endonuclease 1 and DNA polymerase eta associated with replication foci in mammalian S-phase nucleus. Mol Biol Cell 16:2518-2528

Sporbert A, Gahl A, Ankerhold R, Leonhardt H, Cardoso MC (2002) DNA polymerase clamp shows little turnover at established replication sites but sequential de novo assembly at adjacent origin clusters. Mol Cell 10:1355-1365

Sprague BL, McNally JG (2005) FRAP analysis of binding: proper and fitting. Trends Cell Biol 15:84-91

Sprague BL, Pego RL, Stavreva DA, McNally JG (2004) Analysis of binding reactions by fluorescence recovery after photobleaching. Biophys J 86:3473-3495

Stanford NP, Szczelkun MD, Marko JF, Halford SE (2000) One- and three-dimensional pathways for proteins to reach specific DNA sites. EMBO J 19:6546-6557

Stasevich TJ, Mueller F, Brown DT, McNally JG (2010) Dissecting the binding mechanism of the linker histone in live cells: an integrated FRAP analysis. EMBO J 29:1225-1234

Stavreva DA, Muller WG, Hager GL, Smith CL, McNally JG (2004) Rapid glucocorticoid receptor exchange at a promoter is coupled to transcription and regulated by chaperones and proteasomes. Mol Cell Biol 24:2682-2697

Stenoien DL, Patel K, Mancini MG, Dutertre M, Smith CL, O'Malley BW, Mancini MA (2001) FRAP reveals that mobility of oestrogen receptor-alpha is ligand- and proteasome-dependent. Nat Cell Biol 3:15-23

Swagemakers SM, Essers J, de Wit J, Hoeijmakers JH, Kanaar R (1998) The human RAD54 recombinational DNA repair protein is a double-stranded DNA-dependent ATPase. J Biol Chem 273:28292-28297

Tanner TM, Denayer S, Geverts B, Van Tilborgh N, Kerkhofs S, Helsen C, Spans L, Dubois V, Houtsmuller AB, Claessens F, Haelens A (2010) A 629RKLKK633 motif in the hinge region controls the androgen receptor at multiple levels. Cell Mol Life Sci 67:1919-1927

Terry BJ, Jack WE, Modrich P (1987) Mechanism of specific site location and DNA cleavage by EcoR I endonuclease. Gene Amplif Anal 5:103-118

Tsibidis GD (2009) Quantitative interpretation of binding reactions of rapidly diffusing species using fluorescence recovery after photobleaching. J Microsc 233:384-390

Tsibidis GD, Ripoll J (2008) Investigation of binding mechanisms of nuclear proteins using confocal scanning laser microscopy and FRAP. J Theor Biol 253:755-768

van den Broek B, Lomholt MA, Kalisch SM, Metzler R, Wuite GJ (2008) How DNA coiling enhances target 
localization by proteins. Proc Natl Acad Sci USA 105:15738-15742

van Royen ME, Cunha SM, Brink MC, Mattern KA, Nigg AL, Dubbink HJ, Verschure PJ, Trapman J, Houtsmuller AB (2007) Compartmentalization of androgen receptor protein-protein interactions in living cells. J Cell Biol 177:63-72

van Royen ME, Farla P, Mattern KA, Geverts B, Trapman J, Houtsmuller AB (2009) Fluorescence recovery after photobleaching (FRAP) to study nuclear protein dynamics in living cells. Meth Mol Biol 464:363-385

Verschure PJ, van der Kraan I, Manders EM, Hoogstraten D, Houtsmuller AB, van Driel R (2003) Condensed chromatin domains in the mammalian nucleus are accessible to large macromolecules. EMBO Rep 4:861-866

Wachsmuth M, Waldeck W, Langowski J (2000) Anomalous diffusion of fluorescent probes inside living cell nuclei investigated by spatially-resolved fluorescence correlation spectroscopy. J Mol Biol 298:677-689

Wang YM, Austin RH, Cox EC (2006) Single molecule measurements of repressor protein 1D diffusion on DNA. Phys Rev Lett 97:048302

Wright DJ, Jack WE, Modrich P (1999) The kinetic mechanism of EcoRI endonuclease. J Biol Chem 274:31896-31902

Xouri G, Squire A, Dimaki M, Geverts B, Verveer PJ, Taraviras S, Nishitani H, Houtsmuller AB, Bastiaens PI, Lygerou Z (2007) Cdt1 associates dynamically with chromatin throughout G1 and recruits geminin onto chromatin. EMBO J 26:1303-1314

Zotter A, Luijsterburg MS, Warmerdam DO, Ibrahim S, Nigg A, van Cappellen WA, Hoeijmakers JH, van Driel R, Vermeulen W, Houtsmuller AB (2006) Recruitment of the nucleotide excision repair endonuclease XPG to sites of UV-induced DNA damage depends on functional TFIIH. Mol Cell Biol 26:8868-8879 